\title{
The Common Law Remedy of Habeas Corpus Through the Prism of a Twelve-Point Construct
}

\author{
Chuks Okpaluba \& Anthony Nwafor*
}

\begin{abstract}
Long before the coming of the Bill of Rights in written Constitutions, the common law has had the greatest regard for the personal liberty of the individual. In order to safeguard that liberty, the remedy of habeas corpus was always available to persons deprived of their liberty unlawfully. This ancient writ has been incorporated into the modern Constitution as a fundamental right and enforceable as other rights protected by virtue of their entrenchment in those Constitutions. This article aims to bring together the various understanding of habeas corpus at common law and the principles governing the writ in common law jurisdictions. The discussion is approached through a twelve-point construct thus providing a brief conspectus of the subject matter, such that one could have a better understanding of the subject as applied in most common law jurisdictions.
\end{abstract}

Keywords: Habeas corpus, common law, detainee, consitution, liberty

\section{Introduction}

The attitude of the common law ${ }^{1}$ towards the invasion of the individual's right to personal liberty has been stated over the centuries by academics and judges alike as the foundational value of the common law and the constitutional system adopted in common law countries. In his edifice, Blackstone said that protecting the liberty of the individual is 'the first and primary end of human laws'. ${ }^{2}$ The right to liberty, according to this great jurist of the eighteenth century, consists of 'the power of loco motion, of changing situation, or removing one's person to whatever place one's own inclination may direct; without imprisonment or restraint, unless by due course

* $\quad$ Chuks Okpaluba, LLB LLM (London), PhD (West Indies), is a Research Fellow at the Free State Centre for Human Rights, University of the Free State, South Africa. Email: okpaluba@mweb.co.za. Anthony O. Nwafor, LLB, LLM, (Nigeria), PhD (UniJos), BL, is Professor at the School of Law, University of Venda, South Africa. Email: Anthony.Nwafor@univen.ac.za.

1. See generally, J. Farbey and R.J. Sharpe, The Law of Habeas Corpus 3rd ed. (2011); S. Brown, 'Habeas Corpus: A New Chapter' PL 31 (2000).

2. W. Blackstone, Commentary on the Laws of England (1765) vol 1, at 120. of law'3 and that under the common law, 'keeping a man against his will in a private house, putting him in stock, arresting or forcibly detaining him in the street, is an imprisonment'. ${ }^{4}$ These rights belonged to persons 'merely in a state of nature'; these rights and liberties are 'our birth right to enjoy' unless constrained by law. ${ }^{5}$ Lord Halsbury spoke of the liberty of the subject as implications drawn from two interrelated principles:

[T] The subject may say or do what he pleases, provided he does not transgress the substantive law, or infringe the legal rights of others, whereas public authorities may do nothing but what they are authorised to do by some rule of common law or statute. ${ }^{6}$

The courts have long treated the right to personal liberty and access to habeas corpus, which in Roman-Dutch law is known as interdictum de libero homine exhibendo, ${ }^{7}$ as 'inherent' ${ }^{8}$ and a human 'birth right'. 9

The writ of habeas corpus, also known as the 'Great Writ of Liberty', has its roots in the Magna Carta of 1215, the English common man's fountain of liberty, wherein the principle that 'no free man shall be seized or imprisoned except by lawful judgment of his equals or by the law of the land' was first laid down in the fourteenth century; the writ of habeas corpus was used to compel the production of the prisoner in court to ascertain the cause of his or her detention. ${ }^{10}$ From the seventeenth to the twentieth century, the writ was codified in various Habeas Corpus Acts starting with the Habeas Corpus Act 1679, in order to bring clarity and uniformity to its principles and application. This Act was designed to ensure that prisoners entitled to relief 'would not be thwarted by procedural inadequacy'. ${ }^{11}$ In

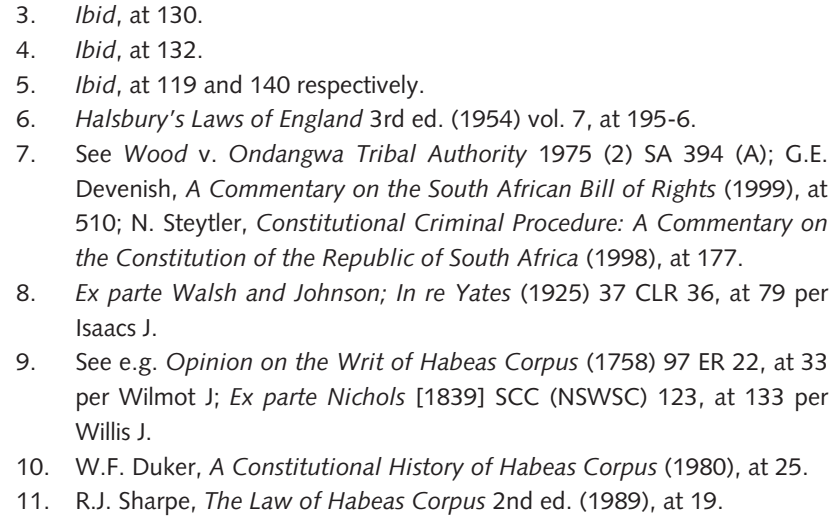

9. See e.g. Opinion on the Writ of Habeas Corpus (1758) 97 ER 22, at 33 per Wilmot J; Ex parte Nichols [1839] SCC (NSWSC) 123, at 133 per Willis J.

10. W.F. Duker, A Constitutional History of Habeas Corpus (1980), at 25.

11. R.J. Sharpe, The Law of Habeas Corpus 2nd ed. (1989), at 19. 
his celebrated lectures on the Lam of the Constitution, Dicey identified two ways in which English law secures the right to personal liberty. The first is by way of redress for unlawful arrest or imprisonment by way of a prosecution or an action, while the second is by deliverance from unlawful imprisonment by means of the writ of habeas corpus. ${ }^{12}$

While the writ of habeas corpus has been incorporated into the Constitution as a fundamental right in countries that have Constitutions incorporating a Bill of Rights, the pattern is different in the case of countries without a written Constitution. For instance, apart from habeas corpus being a common law writ, the New Zealand lawmakers have sought to preserve its application in contemporary New Zealand law through, at least, three separate enactments. The first is the New Zealand Bill of Rights Act 1990 (NZBORA). In terms of Section 23(1)(c) of NZBORA, everyone who is arrested under an enactment 'shall have the right to have the validity of the arrest or detention determined without delay by way of habeas corpus and to be released if the arrest or detention is not lawful'. The second is Section 1140(2)(c) of the Immigration Act 1987. One of the three stipulated events that may lead to the termination of the authority to detain a person who is subject of a security risk certificate is an order of the High Court on an application for a writ of habeas corpus, to release the person. The third illustration comes from the Habeas Corpus Act 2001, Sections 6 and 7 which stipulate the procedural requirements for the court in dealing with applications for a writ of habeas corpus to challenge the legality of a person's detention. Thus, re-enacting the constitutional common law procedural framework of securing immediate release from unlawful detention whereby it must be shown that: (a) there is detention; (b) it is illegal; and (c) it is not voluntary. ${ }^{13}$

\section{The Scope of This Enquiry}

Given the fact that the writ of habeas corpus exists in all common law jurisdictions, and even in civil law jurisdictions where the concept is referred to as interdictum de libero homine exhibendo, the enormity of available materials have ironically seemingly confounded the understanding of the essential attributes of the subject. Therefore, this article seeks to shed clarity on this important subject by, first, limiting the jurisdictions for coverage, and second, discussing concisely the common law jurisprudence emanating from the limited number of selected jurisdictions, namely England, Australia, New Zealand and the United States. The discussion adopts a twelve-point construct whereby the most crucial principles regarding the application for habeas cor-

12. A.V. Dicey, The Law of the Constitution 10th ed. (ECS Wade ed. 1959), at 208.

13. Zaoui v. Attorney General and Others [2005] 1 NZLR 577 (CA), para. 80. See also D. Clark and G. McCoy, Habeas Corpus: Australia, New Zealand, the South Pacific (2000), at 65-6. pus at common law are crafted in the form of twelve propositions. The idea is to present available materials in a manageable form within the existing space. For instance, although the experience of the United States may be found in other units of the construct, the most recent and unique experience in the attempt by the Bush administration to take away through an Act of Congress the right to habeas corpus of the so-called 'enemy combatants' and the response of the Supreme Court provides a distinct construct in its own right. It is that judgment of the Supreme Court declaring Act of Congress unconstitutional that is discussed as the twelfth item of the construct. The other eleven aspects of the common law construct which bring together the law as derived from principally the English, Australia, New Zealand and other jurisdictions complete the subject matter of this article. One thing that is common in all these jurisdictions is that habeas corpus as a common law remedy, and supported by statutory enactments, is so much alive, not only in deportation and extradition matters, but it also features in all forms of detentions and constantly in prison disciplinary matters. With particular regard to the latter point, the Canadian jurisprudence becomes even more uniquely relevant, and for that reason, the Canadian experience is the subject of a separate investigation. ${ }^{14}$ Though the civil law jurisdictions are not explicitly covered in this article, it is believed that by streamlining the subject and depicting the acceptable thresholds in the selected common law jurisdictions, the article provides viable tools for understanding the concept and for a future comparative study of legislative and judicial approaches to the overarching issue of protection of personal liberty in different legal families.

\section{The Common Law Writ of Habeas Corpus: The Twelve- Point Construct}

The limited space inherent in a work of this nature, and the need to keep available materials within manageable reach, demands a concise approach in discussing the operation of the common law writ of habeas corpus based on the law drawn from the various jurisdictions. Thus, the discussion is compressed in a twelve-point proposition constructed around cases decided essentially by the courts in England, Australia and New Zealand as well as the Privy Council judgments from the West Indies. The Canadian experience is briefly and separately discussed. Within this context, it is clear that some overlapping would be inevitable, even in the deliberate attempt to maintain a fairly stringent posture in the clas-

14. C. Okpaluba and A.O. Nwafor, 'Habeas Corpus as a Remedy for Deprivation of the Right to Personal Liberty: Contemporary Developments in Canada and South Africa' 23(10) International Journal of Human Rights 1594-614 (2019) 
sification. However, opportunity is particularly taken to engage, espouse and highlight, inter alia, the distinction drawn by the courts between the application for judicial review and the application for a writ of habeas corpus; the relationship and, sometimes, the blurring lines, between the remedy of habeas corpus and an application for bail; and essentially, the major threat to the remedy as demonstrated by the US Congress enactment of a law that limits the application of habeas corpus in a particular regard.

\subsection{The Divide Between Habeas Corpus and Judicial Review ${ }^{15}$}

An application for a writ of habeas corpus is not an invitation for a court to review the proceedings of an official exercising statutory function, nor does it facilitate collateral attack upon the basis of the judicial exercise of discretion which is in issue in a case. ${ }^{16}$ So, too, habeas corpus cannot be used to challenge a conviction ${ }^{17}$ or sentence of a superior court of record, for these are regarded as valid until they are set aside on appeal or by

15. It was held in $P G$ v. Chief Executive, Ministry of Social Development [2013] NZHC 3089 (21 November 2013), paras. 35-36 that the writ of habeas corpus should be reserved for issues properly susceptible to fair and sensible summary determination - Manuel $v$. Superintendent, Hawkes Bay Regional Prison [2005] 1 NZLR 161, paras. 47-51; E v. Chief Executive, Ministry of Social Development [2005] NZCA 453, para. 91. The real issue in the present case was that Mr G's application was not the lawfulness of the guardianship, custody and parenting orders made in the Family Court, rather he believed that the Family Court has made the wrong decision. However, such concerns cannot be determined in the context of a habeas corpus application. The proper course would be to have raised them in the context of the Family Court proceedings including, if appropriate, by way of appeal from decisions made in the course of those proceedings. Accordingly, the two children, TP and TW were lawfully 'detained' in terms of Section 14 of the Habeas Corpus Act 2001, and hence the orders made by the Family Court relating to their custody, guardianship and parenting were lawfully made under the relevant legislation.

16. $P R$ v. The Department of Human Services [2007] VSC 338, para. 6 .

17. An Irish High Court has held in Re Article 40.4.2 of the Constitution [2015] IEHC 754 (1 January 2015), paras. 7 and 12, that an applicant in post-conviction custody cannot avail himself of the 'extraordinary procedure' of habeas corpus especially where there is no suggestion that his conviction or sentence was bad on its face. Thus, while the applicant may well have a legal right to have his bail application listed before the High Court, his appropriate remedy does not lie in habeas corpus. J. Clarke had held in Arra v. Governor of Cloverhill Prison [2004] IEHC 393 that it is well-established persons convicted upon trial by indictment, are not, in the ordinary way, entitled to release pending an appeal. Persons admitted to bail pending an appeal can only be characterised as being the exception rather than the norm. Even if the applicant can make out some unfairness or illegality connected with a delayed appeal against refusal of bail, he could not thereby be entitled to release from custody or on a writ of habeas corpus. His remedy would be to approach the Court of Appeal to hear his bail application expeditiously. Thus, it was held by C.J. Denman in Ryan v. Governor of Midlands Prison [2014] IESC 54 (22 August 2014), para. 18, that 'the general principle of law is that if an order of a court does show invalidity on its face, in particular if it is an order in relation to post conviction detention, then the route of constitutional and immediate remedy of habeas corpus is not appropriate. An appropriate remedy may be an appeal, or an application for leave to seek judicial review. In certain circumstances, the remedy of Art. 40.4.2 raises only if there has been absence of jurisdiction, a fundamental denial of justice, or a fundamental flaw'. other valid means. ${ }^{18}$ By virtue of this same principle, the orders or warrants of an inferior court or tribunal cannot be challenged under an application for habeas corpus. ${ }^{19}$ It is, however, recognised that a court hearing an application for the writ can determine whether a public authority whose jurisdiction depends on objective facts has a total lack of jurisdiction to make the order or warrant because those facts do not exist. ${ }^{20}$ It is concerned solely with the liberty of the subject which can only be taken away in accordance with the law. A person may not be lawfully imprisoned by a public officer acting in good faith in excess of his authority. The validity of an arrest or a warrant of imprisonment can never depend upon the good faith of the person making the arrest or issuing the warrant. ${ }^{21}$ If the law were otherwise, an innocent third person whose person was wrongfully arrested or whose goods were unlawfully seized would be wholly unprotected. Such a state of affairs would be inconceivable. It is equally inconceivable that a person should be denied the right to obtain his immediate release from an unlawful detention because the person detaining him acted in good faith. ${ }^{22}$

The question with which the UK Supreme Court was confronted in Rahmatullah was whether an entitlement to habeas corpus is coterminous with the right to judicial review. ${ }^{23}$ It was contended that it would be unacceptably incongruous that a different outcome should be possible on an application for a writ of habeas corpus from that which would result from an application for judicial review. In addressing this question, Lord Kerr referred to the opinion of Lord Wilberforce in $R$ v. Secretary of State for the Home Department, Ex parte Kmamaja, ${ }^{24}$ where the latter said:

These remedies of judicial review and habeas corpus are, of course, historically quite distinct and procedurally governed by different statutory rules, but I do not think that in the present context it is necessary to give them distinct consideration. In practice, many applicants seek both remedies. The court considers both any detention which may be in force and order for removal: the one is normally ancillary to the other. I do not think that it would be appropriate unless unavoidable to make a distinction between the two remedies and I propose to deal with both as a common principle.

18. Censori v. Holland [1993] 1 VR 509, at 512 per Harper J; Young v. Registrar, Court of Appeal (No 3) (1993) 32 NSWLR 262, at 285 per P. Kirby; Re Officer in Charge of Cells, ACTSC, Ex parte Eastman (1994) 123 ALR 478 (HCA), at 480 per Deane J; Re Stanbridge' Application (1996) 70 ALJR 640, at 643 per Kirby J; Ah Shueng v. Lindberg [1906] VLR 323, at 327 per Cussen J.

19. Ah Shueng v. Lindberg [1906] VLR 323, at 327.

20. $R$ v. Secretary of State for the Home Department, Ex parte Kwawaja [1984] AC 74, at 101-2, 110, 122-3 and 128; $R$ v. Secretary of State for the Home Department, Ex parte Muboyayi [1992] QB 244, at 254-5.

21. Birch v. Ring [1914] TPD 106

22. Mtetwa v. OC State Prison, Lobatse [1976] BLR 1 (HC), at 4; Cohen Lazar and Co v. Gibbs [1922] TPD 142, at 145.

23. Secretary of State for Foreign and Commonwealth Affairs v. Rahmatullah [2013] 1 AC 614 (UKSC), para. 71.

24. [1984] AC 74, at 99. 
Although the case law is riddled with contradictions and that the modern tendency is to view the writ of habeas corpus as a specific application of principles of common law judicial review to cases affecting the liberty of the subject, the Law Commission maintained that even if both applications are not assimilated, they are 'subject to a common law principle and that the scope of the review of these remedies is and should be essentially the same'. ${ }^{25}$ As much as some might argue that drawing 'a rigid procedural dichotomy' between different prerogative orders 'is no longer justifiable', ${ }^{26}$ others still hap on the overlap inherent in the two remedies. In respect of the latter, it is stated in Halsbury' Lams of England ${ }^{27}$ that

[t]he greatest scope for overlap is where it is alleged that the decision is unlawful because it was based on no evidence or was an unreasonable decision on the available evidence. If an application is made for habeas corpus and the court determines that judicial review should have been sought, the application will not simply be rejected. The court will recognise the true nature of the application and deal with it accordingly.

And as Lord Steyn sums it up, 'pre-eminently, this is an area where substance rather than form governs. Semantics must yield to common sense'. ${ }^{28}$

Lord Kerr further held in Rahmatullah that the fallacy of the argument that habeas corpus should not be available where judicial review is not lies in its conflation of two quite different bases for the claim. The mooted judicial review application would proceed as a challenge to the propriety of the government's decision not to apply to the US authorities for Mr Rahmatullah's return. The application for habeas corpus does not require the government to justify a decision not to make that application. It calls on the government to exercise the control which it appears to have or to explain why it is not possible (not why it is not reasonable) to do so. ${ }^{29}$ According to Lord Kerr, apart from the deferring nature of the two claims, the fact that habeas corpus, if the conditions for the issue are satisfied, is a remedy which must be granted as a matter of automatic entitlement distinguishes it from the remedy of judicial review which can be withheld on a discretionary basis. The remedy of habeas corpus is available as of right for, once there is no real basis for a person's detention, his right to his liberty depends upon no exercise of discretion. Speaking directly on the application in hand, Lord Kerr held:

[I]f it was established that Mr Rahmatullah was unlawfully detained and that the UK authorities had the means of bringing his unlawful detention to the

25. Administrative Law: Judicial Review and Statutory Appeals, Law Com. No 226, HC 669, paras. 11.2 and 11.10.

26. C. Lewis, Judicial Remedies in Public Law (2000), para. 21-012.

27. 4th ed., Reissue (2000) vol. 17(2), para. 1255.

28. Cartwright v. Superintendent, HM Prison (The Bahamas) [2004] 1 WLR 902 (PC), para. 16.

29. Rahmatullah, para. 73. end, it is inconceivable that they could lawfully decline to do so on the basis that it would cause difficulty in the UK's relations with the US. Such a consideration might provide the basis for asserting, in defence of a judicial review application, that the decision not to request the US to take a particular course of action was reasonable. In the context of a habeas corpus application, however, the question of reasonableness in permitting an unlawful detention to continue when the government had the means of bringing it to the end simply does not arise. ${ }^{30}$

\subsection{The Link Between Habeas Corpus and Application for Bail}

When a person is released on bail, he continues to remain in custody, albeit, constructive custody, through surety; his or her liberty remains subject to restraint. An application for habeas corpus can lie in such a circumstance. ${ }^{31}$ However, 'release from detention' is the expression often associated with the writ of habeas corpus, which means, or often refers to, outright release. As Hammond J explained in Zaoui v. $A G:{ }^{32}$

$[\mathrm{H}]$ istorically, habeas corpus was, amongst other things, employed to allow bail. Indeed habeas corpus was at one time a centre-piece of criminal procedure, and the principal method of gaining bail. ${ }^{33}$ Even the famous Habeas Corpus Act 1679 (UK) was specifically designed to address two problems: bail, and the need for a prompt trial. Essentially, a defendant had to be tried within one term or session after his commitment, or bailed and then either tried within two terms or sessions or discharged. Although that Act has now been abolished, it was habeas corpus which gave birth to the notion of the requirement for an expeditious trial - a proposition which has resonated down the centuries, and still presses on us today. And the modern summary forms of applying for bail are a distinct offspring of habeas corpus. ${ }^{34}$

Gleeson CJ held in the Australian High Court case of Al-Kateb v. Godwin ${ }^{35}$ that it was not uncommon to find the interlocutory order of bail made by Mansfield $J$ in the present case as an interlocutory step in habeas corpus proceedings. The Chief Justice of Australia went further to say that, indeed, a proceeding for habeas corpus was once the normal method of applying to the King's Bench for bail. ${ }^{36} \mathrm{He}$ cited the judgment of the English Court of Appeal in an immigration case, where Sir John Donaldson MR (Croom-Johnson and Bingham JJ concurring) held, that the court could grant bail ancillary to or as part of proceedings for habeas corpus. ${ }^{37} \mathrm{As}$

30. Ibid, para. 74

31. Krishma Singh v. State of Bihar (1965) BLJR 35.

32. [2005] 1 NZLR 577 (CA), para. 143.

33. See generally, Sharpe (1989), above n. 11, at 134

34. Zaoui v. Attorney General, para. 143

35. [2004] 219 CLR 562 (HCA), para. 26

36. In Re Kray [1965] Ch 736, at 740; Sharpe (1989), above n. 11, at 128.

37. $R$ v. Secretary of State for the Home Department, Ex parte Torkog/u [1988] QB 398, at 399. 
well as being used to obtain bail, habeas corpus proceedings were commonly brought in disputes relating to custody of children, ${ }^{38}$ or matters concerning the mentally ill. ${ }^{39}$ Gleeson CJ held that it is not antithetical to the nature of habeas corpus for an order to be made upon terms or conditions which relate directly to the circumstances affecting an applicant's right to be released from detention, and reflect temporal or other qualifications upon that right. ${ }^{40}$ It is equally the practice in the United States that courts can release petitioners on condition that they post bonds to act in indicated manners. ${ }^{41}$

\subsection{The Existence of an Alternative Remedy}

Even where judicial review proceedings may be a more suitable vehicle for addressing the particular detention complained of, ${ }^{42}$ the production of a warrant or other document which provides the basis for the detention may be a decisive answer to a habeas corpus application. Where a case is not suitable for summary determination, rights of appeal will also be relevant to a determination of whether habeas corpus should be issued. ${ }^{43}$ Any alternative remedy, however, must be either equally efficacious or even more so than a writ of habeas corpus. ${ }^{44}$ In any case, the existence of an alternative remedy, at least in the New Zealand statutory context, is not a jurisdictional bar to any inquiry into the underlying facts and law of Section 14(2) of the Habeas Corpus Act 2001. That there is another remedy gives a court the power to refuse to make such inquiries where the matter is incapable of summary determination. It does not prevent it from making inquiries in the context of a habeas corpus application into the underlying facts and law if the interest of justice so require. ${ }^{45}$ To hold that the existence of another remedy, even one equally or more efficacious, prevents a court from examining the underlying facts and law when considering a habeas corpus application would not accord with the statutory language in Section 14(2) and with the scheme and purpose of the Act. ${ }^{46}$

The foregoing should be read with some elements of circumspection insofar as the Canadian jurisprudence is concerned. In Canadian law, habeas corpus is an essential remedy and access to it is enshrined in Section 10(c) of the Canadian Charter of Rights and Freedoms 1982. At the same time, and in a somewhat contradictory note, it is well established that in immigration matters, where a complete, comprehensive and expert statutory scheme provides for a review that is at least as broad as and no

38. Per Lord Denman CJ, $R$ v. Greenhill (1836) 111 ER 922, at 927

39. $R$ v. Pinder: In re Greenwood (1855) 24 LJQB 148, at 142 per Coleridge J.

40. Al-Kateb, para. 27.

41. See e.g. US ex rel Chong Mon v. Day 36 F 2d 278, at 279 (1929).

42. Manuel v. Superintendent, Hawkes Bay Regional Prison, paras. 48-49; Campbell v. Superintendent, Wellington Prison [2007] NZAR 52 (CA), para. 35.

43. T(CA222/07) v. Regional Intellectual Care Agency [2007] NZCA 208, paras. 28-30.

44. Ibid, para. 28.

45. Manuel v. Superintendent, Hawkes Bay Regional Prison, para. 49

46. E v. Chief Executive, Ministry of Social Development [2005] NZCA 453, paras. 34-36; PG v. Chief Executive, Ministry of Social Development [2013] NZHC 3089 (21 November 2013), para. 12 per Katz J. less advantageous than habeas corpus, the application for habeas corpus is precluded. This is the so-called 'Peiroo exception', having been derived from the Ontario Court of Appeal judgment in Peiroo v. Minister of Employment and Immigration. ${ }^{47}$ The ratio in Peiroo was explained by Rouleau JA in Chaudhary v. Canada (Public Safety and Emergency Preparedness) ${ }^{48}$ to the effect that a comprehensive alternative remedy to habeas corpus was in place within the administrative structure created to regulate immigration matters, and this alternative remedy was as broad and as advantageous to the detainee as would be habeas corpus. In those circumstances, a provincial superior court should exercise its discretion and decline to grant relief upon the application for habeas corpus.

After an extensive review of the case law including May v. Ferndale Institution ${ }^{49}$ and Mission Institution v. Khe$l a,{ }^{50}$ Rouleau JA held in Chaudhary' $y^{51}$ that the 'Peiroo exception' was not a blanket exclusion of habeas corpus in all matters related to immigration law. In any case, since the issue raised in Chaudhary was not a core immigration issue as in Peiroo and seeks only the determination of the legality of the appellants' continued detentions, these are cases that should be 'carefully evaluated' and, as was laid down in May, 'should not be allowed to expand unchecked'. ${ }^{52}$ This careful evaluation will focus on whether the appellants' remedies for unlawful detention under the Immigration and Refugee Protection Act 2001 (IRPA), including judicial review, with leave, of Immigration Division (ID) detention decisions, are at least as broad as and no less advantageous than that available by way of habeas corpus. In any event, the existence of an alternative remedy to habeas corpus does not mean that the court should automatically decline its jurisdiction. If, as alleged by the respondents, the review process put in place by the IRPA to rule on legality of continued detentions in the appellants' circumstances is as broad as and no less advantageous than on habeas corpus, habeas corpus should be declined. If it is not as broad as and is less advantageous, habeas corpus should be available to the appellants, who would then have the choice of proceeding through the IRPA scheme or through habeas corpus. ${ }^{53}$

It was held, however, that the process of detention review under the IRPA is not as broad and is less advantageous than habeas corpus. Furthermore, the Supreme Court of Canada has recognised the importance of local

47. [1989] 69 OR (2d) 253 (CA)

48. [2015] ONCA 700 (CanLII), para. 60

49. [2005] 3 SCR 809 (SCC).

50. [2014] 1 SCR 502 (SCC).

51. Chaudhary, paras. 74 and 78

52. May, para. 50, where LeBell and Fish JJ for the majority held that the governing rule is that provincial superior courts should exercise their jurisdiction in accordance with the Supreme Court's decisions in the Miller trilogy provided that they should decline habeas corpus jurisdiction only where (a) a statute such as the Criminal Code 1985 confers jurisdiction on a court of appeal to correct errors of a lower court and release the applicant if need be; or (b) the legislator has put in place complete, comprehensive and expert procedure for review of an administrative decision.

53. May, para. 44. 
access to habeas corpus for inmates of both provincial superior courts and federal institutions because of the traditional role of the court as a safeguard of the liberty of the individual. ${ }^{54}$ Thus, detainees in immigration matters who have been detained for a long period with no end to their detention in sight are in similar disadvantaged positions as provincial and federal inmates, and they too have greater local access to a provincial superior court. ${ }^{55}$ Accordingly, the applicants in Chaudhary, who have been in immigration detentions for lengthy periods and whose detentions are to continue for an uncertain duration, should not be deprived of their Charter right to habeas corpus. They have the right to choose whether to have their detention-related issues heard in the Federal Court through judicial review of the ID decisions or in the Superior Court through habeas corpus applications. $^{56}$

\subsection{The Writ Is Available as of Right}

The entitlement to the issue of the writ comes as a matter of right, and it is granted ex debito justitiae. Unlike the remedies of judicial review, it is not a discretionary remedy $;^{57}$ hence, the availability of another remedy is no impediment to its issue. By the same token, if detention cannot be legally justified, entitlement to release cannot be denied by public policy considerations, however important they may appear to be.

If your detention cannot be shown to be lawful, you are entitled, without more, to have that unlawful detention brought to an end by obtaining a writ of habeas corpus. And a feature of entitlement to the writ is the right to require the person who detains you to give an account of the basis on which he says your detention is legally justified. ${ }^{58}$

There is also a corresponding rule that there is no right of appeal from a successful application for habeas corpus absent express statutory authority. ${ }^{59}$ Thus, it was held in a recent Nova Scotia Court of Appeal judgment in Springhill Institution v. Richards ${ }^{60}$ that in the absence of a statutory authority, the Attorney General of Canada, as representing the detainer, has no right to appeal the issuance of the writ or an order of discharge of habeas corpus by the Supreme Court Justice. The broad lan-

54. R v. Gamble [1988] 2 SCR 595, at 635; May, para. 70.

55. Chaudhary, para. 105; Khela, para. 47

56. Chaudhary, para. 113

57. Per Lord Scarman, $R$ v. Secretary of State for the Home Department, Ex parte Kwawaja [1984] AC 74, at 111.

58. Per Lord Kerr, Secretary of State for Foreign and Commonwealth Affairs v. Rahmatullah [2013] 1 AC 614 (UKSC), para. 41; Antunovic v. Dawson [2010] VSC 377 (25 August 2010), para. 149.

59. Cox v. Hakes [1890] 15 App Cas 506, at 514 and 522 per Lord Halsbury LCC; per Lord Bramwell, at 525 and per Lord Herschell, at 530 and 534, respectively. It was held in this case that although Section 19 of the Judicature Act 1873 was couched in very wide terms, it was not in specific enough terms to confer jurisdiction on the Court of Appeal to entertain an appeal against an order of habeas corpus pursuant to which the detainees had been discharged. See also per Lords Clarke and Dyson, Superintendent, Foxhill Prison v. Kozeny [2012] UKPC 10 (28 March 2012), paras. 20-24.

60. [2015] NSCA 40 (CanLII), para. 166. guage found in Section 38 of the Judicature Act is insufficient, in light of the decisions of the House of Lords ${ }^{61}$ and in Canadian Courts ${ }^{62}$ - particularly, in light of the Legislature's decision to grant to the prisoner a right of appeal in the Liberty of the Subject Act, and not a detainer. Consequently, the appeal from the order discharging respondent from unlawful detention was accordingly dismissed for want of jurisdiction. Leave to appeal from the interlocutory orders was granted, but both appeals were dismissed. ${ }^{63}$

If the applicant can apply for the writ as of right, can he or she enjoy the right to appeal against a refusal to grant the application as many times as the courts refuse his or her application? The Canadian case of $U S A$ v. Desfoss$e s^{64}$ serves as an illustration. The applicant who was ordered to be extradited to the United States of America by the order of a judge brought several motions in relation to the appeals and applications for leave to appeal from the alleged refusal of writs of habeas corpus. The motions raised an issue of jurisdiction of the Superior Court to entertain appeals as of right in respect of the disposition of the applications for habeas corpus in the courts below. Sopinka J held that the first application was heard on the merits. Moreover, an appeal was heard on the merits pursuant to Section 784(5) of the Criminal Code 1985 consequent upon which the applicant sought leave to appeal. Leave was refused and an application for reconsideration was also refused. The applicant has therefore had his application determined on the merits and had thereby exhausted his appeals. He was therefore not entitled to start all again as if the matter were 'tabula rasa'. The applicant could not be heard to allege that he had been 'refused' a writ of habeas corpus and that Section 784(3) applied. Since he had a hearing on the merits pursuant to a consent procedure which treated the writ as having been issued, the applicable section for the purposes of appeal is Section 784(5) of the Act. The applicant, therefore, could not appeal as of right with respect to any of the judgments which dismissed his appeals in the second, third and fourth applications. As the court had no jurisdiction to hear appeals as of right, the application to extend the time to appeal suffered the same

61. Cox v. Hakes [1890] 15 App Cas 506, at 522 where Lord Halsbury LC held that although the subject whose liberty was at stake was historically allowed to make repeated applications for the writ, but if successful, no writ of error or demurer was allowed. In Secretary of State for Home Affairs v. O'Brien [1923] AC 603, at 617-18, it was Viscount Finlay who clearly explained that not only was there no right of appeal from an order of discharge, but that there was no right of appeal from the issuance of the writ. See now Section 15, Administration of Justice Act 1960 (UK), which provides for a right of appeal in civil or criminal habeas corpus proceedings, whether the applicant secures his release or not.

62. In Re Storgoff [1945] SCR 526 where the Supreme Court of Canada held that since the Criminal Code at the time provided no right of appeal in criminal habeas corpus matters, the Court of Appeal was wrong to have cancelled the order of discharge on the return of a writ of habeas corpus. In R v. MacKay [1956] 2 DLR (2d) 358, the Supreme Court in banco was unanimous that the Attorney General had no right of appeal where a County Court judge had discharged the respondent from custody from an order in the nature of habeas corpus.

63. Springhill, paras. 232-233 and 235.

64. [1997] 2 SCR 326, para. 11. 
fate. It would seem that while the applicant can appeal against refusal of the order, such an appeal only lies with the leave of court.

\subsection{A Swift and Imperative Remedy}

The remedy of habeas corpus is imperative, peremptory and swiftly obtained. ${ }^{65}$ Since this reflects the fundamental importance of the right to liberty, it is a flexible remedy adaptable to changing circumstances. ${ }^{66}$ In other words, the purpose of the writ is to provide swift and effective vindication of the personal liberty of the individual in cases where it is being unlawfully restrained. ${ }^{67}$ As Martin JA put it in $R$ v. McAdam: this 'very high prerogative' and 'transcendent' writ in English law,

is a civil right, the assertion of which in all cases is by its own peculiar and summary procedure which does not vary in essentials whether the custody be under criminal process, or civil, or military, or naval, or private, or governmental executive Act, or otherwise: its whole procedure with its 'peculiarities' is extraordinary and entirely apart and distinctive from the ordinary proceedings that it reviews, and brings the person detained thereunder before the Court or Judge so that the appropriate remedy may be applied. ${ }^{68}$

Referring to this quotation, the Saskatchewan Court of Appeal held in Ross v. Riverbend Institution (Warden) ${ }^{69}$ that the nature of the prerogative writ of habeas corpus is a procedural writ which may apply in a criminal or civil matter but it is the proceeding under which the applicant is placed in custody which determines whether the character of the habeas corpus proceeding is criminal or civil.

The great policy of habeas corpus is that the legality of restraint on the person's freedom will be 'determined summarily and finally'. ${ }^{70}$ As de Smith has described the writ, it is 'a fast and effective method of challenging cases of illegal unlawful detention' ${ }^{71}$ From the earliest days of the writ, the emphasis has been on the speed of disposition such that the 1640,1679 and 1816 Habeas Corpus Acts (UK) were designed to overcome the delays in determining the legality of the detention; to introduce procedural reforms to combat delays; and to achieve the objective of habeas corpus application being as it ought to be an 'expeditious and effectual method of restoring any person to his liberty'. ${ }^{2}$ The jurisdiction is

65. Per Lord Birkenhead, Rex v. Secretary of State for Home Affairs, Ex parte O' Brien [1923] AC 603, at 609.

66. $R$ v. Secretary of State for the Home Department, Ex parte Muboyayi [1992] QB 244, at 269 per Taylor LJ.

67. Ex parte $O^{\prime}$ Brien, at 609; Ex parte Walsh and Johnson: In Re Yates [1925] 37 CLR 36, at 77 per Isaacs J.

68. Quoted in Ross v. Riverbend Institution (Warden) 2008 SKCA 19 (CanLII), para. 24

69. Ibid, paras. 26-28.

70. Per Lord Halsbury LC, Cox v. Hakes [1890] 15 App Cas 506, at 522; $R$ v. Kerr, Ex parte Groves [1973] Qd R 314, at 316.

71. H. Woolf, J.L. Jowell and A.P. Le Sueur, De Smith's Judicial Review of Administrative Action 6th ed. (2007), at 17-103.

72. Antunovic v. Dawson, para. 79. broad, flexible and adaptable. ${ }^{73}$ Habeas corpus applications are given priority in the business of the courts. In such applications, the court has a positive duty to consider and determine the legality of the restraint. ${ }^{74}$

\subsection{Objective Is to Release a Person Detained Unlawfully}

The object of the writ is not to punish previous illegality, and it will only issue to deal with release from current unlawful detention. ${ }^{75}$ The question, then, is: what is the purpose of the writ of habeas corpus? Or, put differently, what is the importance of the remedy? The often cited speech of Bankes LJ in $R$ v. Secretary of State for Home Affairs, Ex parte O'Brien explains the importance of the remedy. The Lord Justice had said that

[t]he duty of the court is clear, the liberty of the subject is in question whether the order of the internment complained of was or was not lawfully made. The Act is a very drastic one indeed on an individual. Parliament has seen fit to curtail the liberty of an individual in order to protect that of the state: Parliament has seen fit to give to an individual the authority to terminate another individual's liberty is of a certain opinion. The detained person is at the mercy of that individual as to when he will be allowed to regain

73. Wilmot J had in Opinion on the Writ of Habeas Corpus (1758) 97 ER 29 , at 39 , described the process as drawing a 'principle out into action, and a legal application of it to attain the ends of justice'. Similarly, Lord Donaldson described habeas corpus as 'the greatest and oldest of all the prerogative writs, is quite capable of adapting itself to the circumstances of the times' $-R$ v. Secretary of State for the Home Department, Ex parte Muboyayi [1992] QB 244, at 258. In Al-Kateb v. Godwin [2004] 219 CLR 562 (HCA), paras. 24-28, Gleeson CJ said of writ or an order in the nature of habeas corpus as 'a basic protection of liberty, and its scope is broad and flexible'. Lord Donaldson's speech above was adopted and affirmed. In R v. Gamble [1988] 2 SCR 595, para. 66, Wilson J speaking at the Supreme Court of Canada wrote: 'A purposive approach should, in my view, be applied to the administration of Charter remedies as well as to the interpretation of Charter rights and, in particular, should be adopted when habeas corpus is the requested remedy since that remedy has traditionally been used and is admirably suited to the protection of the citizen's fundamental right to liberty and the right not to be deprived of it except in accordance with the principles of fundamental justice. The superior courts of Canada have, I believe, with the advent of the Charter and in accordance with the sentiments expressed in the habeas corpus trilogy of Miller, Cardinal and Morin, displayed both creativity and flexibility in adapting the traditional remedy of habeas corpus to its new role. I find it instructive the following innovative uses of habeas corpus as a Charter remedy: Re Cadeddu and the Queen 1982 CanLII 2138 (ONSC); Swan v Attorney General of BC 1983 CanLII 332 (BCSC); Lussa v Health Science Centre (1983) 9 CRR 350 (Man. QB); MacAllister v Director of Centre de Reception (1984) 40 CR (3d) 121 (Que. SC); Re Marshall and the Queen (1984) 13 CCC (3d) 73 (Ont. HC); Re Jenkins (1984) 8 CRR 142 (PEISC in banco); Jollimore $v$ Attorney General of Nova Scotia (1986) 24 CRR 28 (NSSC); Balian v Regional Transfer Board (1988) 62 CR (3d) 256 (Ont.HC).'

74. Antunovic v. Dawson [2010] VSC 377 (25 August 2010), para. 146. As Hammond J put it in Zaoui v. Attorney General [2005] 1 NZLR 577 (CA), para. 133, 'So important is the writ, and so wide its reach, that no leave of the court is required to apply for it. Indeed, a judge of the High Court will (if necessary) deal with the particular matter at any time. The application for the writ must be given a priority hearing, above all other business of the court.'

75. Per Lord Evershed MR, Ex parte Mwenya [1960] 1 QB 241, at 303. 
his liberty ... it is the main function of the courts in our Kingdom to protect the rights of an individual. It is equally the function of Parliament. If those rights are infringed or curtailed, however slightly, and the situation is brought to the notice of the courts, courts will jealously guard against such an erosion of the individual rights. Any person who infringes or takes away the rights of an individual must show a legal right to do so. The rights of an individual being infringed or taken away, even if a legal right is shown, the courts will scrutinize such legal right very closely indeed. If it is an Act of Parliament, the court will give it the usual strict interpretation in order to see whether the provisions of the said Act have been strictly observed. If the courts come to the conclusion that the provisions of such an Act are not being strictly observed then the detention of the detainee would be illegal and the court will not hesitate to say so. ${ }^{76}$

As the Court of Appeal in New Zealand has held, 'traditionally the writ [of habeas corpus] has been used only where it is sought to release someone entirely from (unlawful) custody'. ${ }^{77}$ The court also emphasised that the scope of the writ should 'not be shackled by precedent' and that the writ will 'adapt and enlarge as new circumstances require'. ${ }^{78}$ Nevertheless, McGrath J held in Zaoui v. Attorney General that in providing that an order, made on a habeas corpus application, could be the basis for release of a person detained under Part 4A's provisions of the Immigration Act 1987, Parliament had in mind situations in which the detaining authority could not show there was a legal justification for the detention concerned. That situation might arise in the habeas corpus proceeding itself or in a habeas corpus proceeding brought following a successful judicial review proceeding under the Judicature Amendment Act 1972 in which it was established there was a lack of authority to detain the person the subject of the security certificate. The appropriate procedure may depend on whether the legality can be demonstrated in a summary process. ${ }^{79}$ The scope of the circumstances in which an order covered by Section 1140(2)(c) of the Immigration Act 1987 might be made would accordingly cover situations where there was a serious irregularity in the warrant or where the statutory purpose of deportation following confirmation of the security certificate could no longer be achieved and there was no basis for continuing decision. This is the nature of the event terminating authority to detain under Section 1140(2)(c). Habeas corpus does not provide a general power for the court to allow conditional release of a person lawfully detained. ${ }^{80}$

76. [1923] (2) KB 361, at 375

77. Bennett v. Superintendent, Rimutaka Prison [2002] 1 NZLR (CA) 616 para. 61; Zaoui v. Attorney General [2005] 1 NZLR 577 (CA), para. 81.

78. Bennett, para. 60

79. Zaoui v. AG, para. 82; Bennett, paras. 59-74; Manuel v. Superintendent, Hawkes Bay Regional Prison CA67/04 (15 June 2004), paras. 49-51.

80. Zaoui v. AG, para. 83

\subsection{Restraints Amenable to Habeas Corpus}

The effectiveness of the remedy of habeas corpus would be substantially reduced if it was not available to require someone who had the means of securing the release of a person unlawfully detained to do so, simply because he did not have physical custody of the detainee ${ }^{81}$ for, as Atkin LJ held in Ex parte O' Brien, 'actual physical custody is obviously not essential' ${ }^{82}$; or Vaughan Williams LJ put it: 'the writ may be addressed to any person who has such control over the imprisonment that he could order the release of the prisoner'. ${ }^{83}$ At the heart of cases on control in habeas corpus proceedings lies the notion that the person to who the writ is directed has either actual control of the custody of the applicant or at least the reasonable prospect of being able to exert control over his custody or to secure his production to the court. ${ }^{84}$ Thus, the appropriate respondent to a writ of habeas corpus is the person who has actual control of the custody of the detainee or at least a reasonable prospect of being able to exert a sufficient degree of control or secure his production to the court. ${ }^{85}$

Put differently, the proper respondent to a habeas corpus application is the person who asserts a lawful authority of custody, power or control over the applicant's personal liberty and the person, or the person responsible for managing the institution or place which is carrying out the physical restraint. ${ }^{86}$ Lord Kerr further held in Rahmatullah that whether a person could exert such control was a question of fact and not of the legal enforceability of a right to assert such control. ${ }^{87}$ Where it was uncertain whether the respondent had such control, the court could properly issue the writ to determine that matter on the return with fuller knowledge. The memorandum, assuming it was honoured, provided more than sufficient reason to conclude that the respondents could successfully request the applicant's return, but they claimed that it was unenforceable

81. The US Supreme Court has held in Jones v. Cunningham 371 US 236 (1863), at 239-40, that the use of habeas corpus has not been restricted to situations in which the applicant is in actual physical custody and that '[h]istory, usage and precedent can leave no doubt that, besides physical imprisonment, there are other restraints on a man's liberty, restraints not shared by the public generally, which have been thought sufficient in the English-speaking world to support the issuance of habeas corpus'.

82. [1923] (2) KB 361, at 398

83. R v. Earl of Crewe, Ex parte Sekgome [1910] 2 KB 576, at 592.

84. Barnardo v. Ford [1892] AC 326, at 338 and 340, respectively, where Lord Herschell held that the writ will be issued where someone was 'in unlawful custody, power or control' of another person while Lord MacNaghten said that the issue was whether the person was under the 'control or within ... reach' In $R$ v. Secretary of State for Home Affairs, Ex parte O' Brien [1923] 2 KB 361 (CA), at 391-2, habeas corpus was issued against the Home Secretary pursuant to undertakings given by the Irish Free State Government. The Court of Appeal held that that was enough to require a return. The House of Lords dismissed the appeal - Secretary of State for Home Affairs, v. O' Brien [1923] AC 603.

85. Per Lord Kerr, Secretary of State for Foreign and Commonwealth Affairs v. Rahmatullah [2013] 1 AC 614 (UKSC), paras. 45 and 64. See also May v. Ferndale Institution [2005] 3 SCR 809 (SCC) and the more recent case of Mission Institution v. Khela [2014] 1 SCR 502 (SCC).

86. Antunovic v. Dawson [2010] VSC 377 (25 August 2010), para. 147

87. Rahmatullah, para. 48. 
and superseded by a later agreement and that a request would be futile. The Court of Appeal, in its first judgment, was justified in concluding that there was sufficient uncertainty in issuing the writ. In doing so it required the respondents to test whether they had, in fact, control of the applicant and, if appropriate, to demonstrate why it was not possible to secure his return. That did not amount to an instruction or other impermissible interference within the 'forbidden' territory ${ }^{88}$ of the executive's diplomatic relationship with the United States. However, the United States, aware of the basis on which the Court of Appeal considered that the respondents had retained control, was explicit in its assertion that it was legally entitled to hold the applicant. ${ }^{89}$ It was clear that there was no opportunity for further discussion. The Court of Appeal, in its second judgment, was therefore entitled to conclude that the respondents had made a sufficient return and to make no further order on the writ. ${ }^{90}$

It does happen when the restraint is being imposed by someone whose alleged lawful custody, power or control is a step removed from those who are imposing the physical restraint. Where the restraint is being imposed at the direction of someone who asserts the contested legal authority from a physical distance, that person is also a proper respondent to an application for habeas

88. This is in reference to matters of the executive's conduct in relation to foreign affairs which in $R$ v. Secretary of State for Foreign and Commonwealth Affairs, Ex parte Pirbhai [1985] 107 ILR 462, at 479, where Sir John Donaldson said that 'it can rarely, if ever, be for judges to intervene where diplomatists fear to tread'. Similar sentiment was expressed by Lightman J in R v. Secretary of State for Foreign and Commonwealth Affairs, Ex parte Ferhut Butt [1999] 116 ILR 607, para. 12 to the effect that 'the general rule is well established that the courts should not interfere in the conduct of foreign relations by the Executive, most particularly, where such interference is likely to have foreign policy repercussions $-R$ v. Secretary of State for Foreign and Commonwealth Affairs, Ex parte Everett [1999] 1 QB 811, at 820. This extends to decisions whether or not to seek to persuade a foreign government to take any action or remind a foreign government of any international obligation (e.g. to respect human rights) which it has assumed'. The foregoing is in a way saying that matters of foreign relations are not justiciable for, as Lord Phillips MR put it in R (Abbasi) v. Secretary of State for Foreign and Commonwealth Affairs and Secretary of State for the Home Department [2003] EWCA Civ. 1598, para. 106 (iii) that 'the court cannot enter the forbidden areas, including decisions affecting foreign policy'. Again, Laws LJ held in $R$ (Al Rawi) v. Secretary of State for Foreign and Commonwealth Affairs (UNCR intervening) [2008] QB 289, para. 148 that '[t]his case has involved issues touching both the Government's conduct of foreign relations, and national security: pre-eminently the former. In those areas the common law assigns the duty of decision upon the merits to the elected arm of government; all the more so if they combine in the same case. This is the law for constitutional as well as pragmatic reasons'.

89. Rahmatullah, paras. 60 and 68. The argument was that the issue of the writ of habeas corpus in this case represented an intrusion by the courts in the area of foreign policy, an area which the courts scrupulously avoid. Rejecting this argument as flawed, Lord Kerr held that the decision of the Court of Appeal that there were grounds on which it could be concluded that the Secretaries of State could exercise control over Mr Rahmatullah's custody and that they were therefore required to make a return to the writ does not entail an intrusion into the area of foreign policy. It does not require the government to take any foreign policy stance; it merely seeks an account as to whether it has, in fact, control or an evidence-based explanation as to why it does not.

90. Rahmatullah, para. 76 . corpus. ${ }^{91}$ In such a case, the proper course is to name the superintendent or manager of the institution having physical custody of the person, as well as the person having lawful authority. ${ }^{92}$ For instance, in $R$ v. Wright, ${ }^{93}$ the doctor having the care of the mentally ill person was the respondent while in $R$ v. Turlington, ${ }^{94}$ it was the 'keeper' of the private house who produced the person concerned and who 'was confined there by her husband'. So, too, in Re Shuttlemorth ${ }^{95}$ the respondent was the proprietor of a licensed private house for mentally ill people who claimed that the person concerned 'was delivered into my custody'. In the leading case of $R \mathrm{v}$. Board of Control, Ex parte Rutty ${ }^{96}$ the respondents were the medical superintendent of the institution for mentally ill persons in which the person was being detained and the board who authorised her detention.

\subsection{Scope of Application of the Writ}

The writ of habeas corpus is not confined to arrest and imprisonment; it applies where anyone having custody, power or control over another person imposes restraints on their liberty which are not shared by the general public. It applies to partial ${ }^{97}$ as well as total restraint. ${ }^{98}$ In effect, the court's jurisdiction in this matter covers, but is not limited to, unlawful imprisonments and other forms of detention; it extends to all unlawful restraints upon a person's freedom of movement which are not shared by the public generally. ${ }^{99}$ Drawing out of the underlying principle of personal liberty which the remedy actually protects, it would cover a case where the applicant's freedom of movement and freedom to choose where to live are being restrained, even if only partially, and the principle takes the remedy with it. Indeed, habeas corpus is not just an available remedy in such a case; it is the most efficacious remedy. ${ }^{100}$

\subsection{Burden of Proof}

There is a presumption at common law in favour of liberty $^{101}$ and a corresponding obligation on the part of those who would restrict it to demonstrably establish the lawfulness of that restriction. In other words, every person is presumed entitled to personal freedom of the

91. Antunovic v. Dawson, para. 92.

92. Somerset v. Stewart [1772] 98 ER 499.

93. [1731] 93 ER 939.

94. [1761] 97 ER 741.

95. [1846] 9 QB 651. See also $R$ v. Pinder; in Re Greenwood [1855] 54 LJKB 148 , at 150 and 153

96. [1956] 2 QB 109, at 112.

97. Ruddock v. Vadarlis [2001] FCA 1329 (18 September 2001).

98. Antunovic v. Dawson [2010] VSC 377 (25 August 2010), para. 196

99. Antunovic v. Dawson, para. 147

100. Antunovic v. Dawson, para. 177. It was held in this case (paras. 170-176) that Ms Antunovic's freedom was being restrained in that she was being required to live in a Community Care Unit at night and prevented from going to live in the place of her choosing. This restricted her freedom of movement under Section 12 of the Charter. Even though the restraint was partial and not total, but was amenable to the writ of habeas corpus, because they were not shared by the general public who, under the common law, can generally choose where to live, and go to and from their home, at will. Being able to do so is an important aspect of private and social life and the development of the individual, including that which occurs in their own family.

101. Ex parte Walsh v. Johnson, In re Yates (1925) 37 CLR 36 (HCA), at 79. 
body ${ }^{102}$ so that when a court considers the legality of a restraint on personal liberty, its starting point is the presumption that it is prima facie illegal at common law until the contrary is proved. This principle was stated by Lord Atkin in Liversidge v. Anderson ${ }^{103}$ when he said that

a principle which again is one of the pillars of liberty is that in English law every imprisonment is prima facie unlawful ${ }^{104}$ and that it is for the person directing imprisonment to justify his act.

Because the presumption is in favour of liberty, there is no room for the application of other presumptions such as the presumption in favour of the Crown ${ }^{105}$ or the common law rule presuming the regularity of official acts has no relevance. ${ }^{106}$ The legality of the detention must be demonstrably established by the respondent who bears the general onus as to the legality of the detention. ${ }^{107}$ Although the standard of proof required is that of civil proceedings, on a balance of probability, it must be applied in a manner that takes account of the importance of protecting the personal liberty of the individual. ${ }^{108}$ For, as Lord Scarman held in Ex parte Kmamaja, 109 'the flexibility of the civil standard of proof suffices to ensure that the court will require the high degree of probability which is appropriate for what is at stake'. Again, as Bell J held in Antunovic v. Dawson: ${ }^{110}$

Requiring a high degree of probability in habeas cor-

pus proceedings is consistent with the approach adopted in Victoria to determining whether a limitation is demonstrably justified under s 7(2) of the Charter. ${ }^{111}$ Referring to the judgment of Denning LJ in Baxter $v$ Baxter, ${ }^{112}$ in Application under Major Crimes (Investigative Powers) Act 2004, Warren CJ said [that] the standard of proof required was high. ${ }^{113}$ The Chief Justice went on to apply the principle

102. Per Sholl J, R v. Governor of Metropolitan Gaol; Ex parte Di Nardo [1963] VR 61, at 62.

103. [1942] AC $206(\mathrm{HL})$, at 245

104. See also $R$ v. Secretary of State for the Home Department, Ex parte Khawaja [1984] 1 AC 74, at 110 per Lord Scarman; Ruddock v. Vadarlis [2001] 110 FCR 491, para. 73 per Black CJ; Hicks v. Ruddock [2007] 156 FCR 574 para. 53 per Tamberlin J; M. Aronson, B. Dyer \& M. Groves, Judicial Review of Administrative Action 4th ed. (2009), at 14.105.

105. Dillon v. $R$ [1982] AC 484 (PC), at 487.

106. Schlieske v. Federal Republic of Germany [1987] 71 ALR 215, at 223 per Fox, Wilcox and Burchett JJ.

107. $R$ v. Davey; Ex parte Freer [1936] 56 CLR 381 (HCA), at 385 per Evatt J; Trobridge v. Hardy (1955) 94 CLR 147 (HCA), at 152 per Fullager J; $R$ v. Governor of Metropolitan Gaol; Ex parte Di Nardo [1963] VR 61, at 62 per Sholl J.

108. Briginshaw v. Briginshaw [1938] 60 CLR 336, at 362-3 per Dixon J.

109. [1984] 1 AC 74, at 110. See also per Denning LJ, Baxter v. Baxter [1951] P 35, at 37; per Dixon J, Wright v. Wright (1948) 77 CLR 191 (HCA), at 210.

110. [2010] VSC 377, para. 124.

111. Referring to Charter of Human Rights and Responsibilities Act 2006 (Vic.).

112. Baxter v. Baxter [1951] P 35, at 37

113. [2009] VSC 381, para. 147. expounded by Dickson CJ in $R v$ Oakes $^{114}$ that the evidence should be 'cogent and persuasive and make clear to the Court the consequences of imposing or not imposing the limit'.

\subsection{Successive Application for the Writ}

A series of applications can be made for the writ of habeas corpus on the same matter. However, a second application will not be permissible if the idea would be to go over the judgment in the first application. There must be fresh evidence, or a new ground must have arisen. That such a ground was missed in the previous application cannot be a ground for a second application. ${ }^{115}$ This position has been attained in several jurisdictions either by judicial decisions ${ }^{116}$ or by statutory amendment ${ }^{117}$ or through incorporation in the rules of court. ${ }^{118}$ Otherwise, the principle at common law prior to the amalgamation of the then existing courts in England into one High Court by the Judicature Acts 1873-1875 was that each court could hear an application for habeas corpus de novo on its merits, because the refusal of the writ was not regarded as a judgment and therefore the matter was not res judicata. ${ }^{119}$ However, dicta from the House of Lords ${ }^{120}$ and the Privy Council held that Parliament could not have intended to restrict

114. [1986] 1 SCR 103, para. 43. In similar tone, the Full Court of the Supreme Court of Western Australia held in Truong v. Manager, Immigration Detention Centre, Port Hedland (1993) 31 ALD 729, at 731, that since the liberty of the applicant was at stake, the habeas corpus application would require 'strong, clear and cogent evidence'. See to the same effect, Neat Holdings Pty Ltd v. Karajan Holdings Pty Ltd (1992) ALJR 170, at 171-2.

115. Chandra Prakash Agarwala v. SC Bose Mullick ILR (1967) 1 Punj 517. See generally, V.G. Ramachandran, Fundamental Rights and Constitutional Remedies (1959) vol. II, at 793.

116. In re Hastings (No 1) [1958] 1 WLR 372 (DC); In re Hastings (No 2) [1959] 1 KB 358, at 374-5; In re Hastings (No 3) [1959] Ch. 368, at 377 and 380

117. Section 14(2), Administration of Justice Act 1960 (UK).

118. In the Australian State of Victoria, Order 57 on 'Habeas Corpus', Rule 57.04 provides that 'when an order for a writ is refused, an application for a writ shall not be made again in respect of the same person on the same grounds, whether to the same judge of the court or to any other judge of the court, unless fresh evidence is adduced'. The Court of Appeal of Victoria held in Censori v. Adult Parole Board [2015] VSCA 254 (17 September 2015), paras. 61-65, that in terms of the rule, it follows that if an unsuccessful applicant for habeas corpus makes a further application to the court, it is first necessary to ask whether it is made on the same ground as the previous application. To the extent that it is, such a ground may only be advanced if fresh evidence is adduced in respect of it. To the extent that the application is made on different grounds, or on the same grounds but supplemented with fresh evidence, the court retains its inherent power to dismiss the proceedings as an abuse of process, making due allowance for the fact that the liberty of the subject is in issue. That means that the trial judge was correct to have dismissed the application as a re-litigation of a matter already decided upon. Warren CJ, Ferguson and McLeish JJ held: 'In our opinion, the matter before Harper J directly raised the issues now sought to be pressed in grounds 3 and 4 . They are the same grounds as were previously raised and, as the judge in the present case held, they were resolved adversely to the appellant in that proceeding. They can therefore only be pursued if fresh evidence is adduced in support of them.'

119. H. Phillips and P. Jackson, Hood Phillips' Constitutional and Administrative Law 7th ed. (1987), at 509-10; L. Goddard, 'A Note on Habeas Corpus' 65 LQR 30 (1949). Cf. D.M. Gordon, 'The Unruly Writ of Habeas Corpus' 26 MLR 520 (1963).

120. Cox v. Hakes (1890) 15 App Cas $506(\mathrm{HL})$. 
the rights of the subject in the vital matter of personal liberty which meant that the detainee reserves the right to apply to each Division of the High Court, and also to each High Court judge individually. In the Privy Council case - Eshugbayi Eleko v. Government of Nigeria (Officer Administering) ${ }^{121}$ - the appellant had given a fresh notice of motion for the issue of a writ of habeas corpus in the Supreme Court of Nigeria after a previous motion for the same relief had been rejected. He contended that he was entitled to make successive applications to the same court. The respondent admitted that a right to make successive applications for habeas corpus exists, but only to different courts. The Privy Council held that the Judicature Acts had not intended to cut down the availability of habeas corpus for each judge of the High Court still has jurisdiction to entertain an application for a writ of habeas corpus in term or in vacation, and that each judge is bound to hear and determine such an application on its merits notwithstanding that some other judge has refused a similar application. ${ }^{122}$

The Supreme Court of the United Sates was considering in McCleskey v. Zant ${ }^{123}$ the basis of the doctrine of abuse of the writ, which defines the circumstances in which federal courts decline to entertain a claim presented for the first time in a second or subsequent habeas corpus petition. It was held that although the Court's habeas corpus decisions do not all admit of ready synthesis, a review of the precedents demonstrates that a claim need not have been deliberately abandoned in an earlier petition in order to establish that its inclusion in a subsequent petition constitutes abuse of the writ; ${ }^{124}$ that such inclusion constitutes abuse if the claim could have been raised in the first petition, but was omitted through inexcusable neglect; ${ }^{125}$ and that, because the doctrines of procedural default and abuse of the writ implicate nearly identical concerns, the determination of inexcusable neglect in the abuse context should be governed by the same standard used to determine whether to excuse a habeas petitioner's state of procedural defaults. ${ }^{126}$ Thus, when a prisoner files a second or subsequent habeas petition, the state bears the burden of pleading abuse of the writ. This burden is satisfied if the

121. [1928] AC 459 (PC).

122. Ibid, at 468 per Lord Hailsham LC.

123. 499 US 467 (1991).

124. See e.g. Sanders v. US 373 US 1, at 18-19 (1963).

125. Delo v. Stokes 495 US 320 (1990) where it was held that a stay of execution pending disposition of a second or successive federal habeas petition can be granted only where there are substantial grounds upon which relief can be granted. In the present case, there were no such grounds, because the respondent's fourth petition clearly constituted an abuse of the writ. His claim could have been raised in his first petition for federal habeas, and the principle he asserted were not novel and could have been developed long before the current application.

126. Wainwright v. Sykes 433 US 72 (1977), at 87-8, 91. It was held in this case that a federal habeas petitioner who has failed to comply with a State's contemporaneous objection rule trial must show cause for the procedural default and prejudice attributable thereto in order to obtain review of his defaulted constitutional claim. At any rate, this case plainly implied that default of a constitutional claim by counsel pursuant to a trial strategy or tactical decision would, absent extraordinary circumstances, bind the habeas petitioner even if he had not personally waived that claim. state, with clarity and particularity, notes petitioner's prior writ history; identifies the claims that appear for the first time; and alleges that petitioner has abused the writ. The burden to disprove abuse then shifts to the petitioner. To excuse his failure to raise the claim earlier, the petitioner must show cause, for instance, that the petitioner was impeded by some objective factor external to the defence, such as governmental interference or the reasonable unavailability of the factual basis for the claim - as well as actual prejudice resulting from the errors of which the petitioner complains. The petitioner will not be entitled to evidentiary hearing if the district court determines as a matter of law that the petitioner cannot satisfy the cause and prejudice standard. However, if the petitioner cannot show cause, the failure to raise the claim earlier may nonetheless be excused if the petitioner can show that a fundamental miscarriage of justice - the conviction of an innocent person - would result from a failure to entertain the claim. McCleskey has not satisfied the foregoing standard for excusing the omission in the first federal habeas corpus petition. $\mathrm{He}$ lacks cause for that omission, and therefore, the question whether he would be prejudiced by his inability to raise the claim need not be considered. ${ }^{127}$

\subsection{Writ Not Subject to Suspension or Deferment}

Personal liberty and security being a 'first and primary end' of the law, ${ }^{128}$ it is the responsibility of the courts not only to 'see to it' ${ }^{\text {' }}$ but it is their 'duty'130 to protect it. The court's obligation in this regard applies equally in times of war, because, judges at all times, 'stand between the subject and any encroachments on their liberty, alert to see that any coercive action is justified in law'. ${ }^{131}$ Thus, the idea of the suspension or deferment of habeas corpus is a matter of gravest constitutional moment, ${ }^{132}$ and historically has only occurred in wartime, or in critical national emergencies. ${ }^{133}$ The notion of non-suspension or deferment, observed Hammond J in Zaoui, is 'deeply enshrined in English law'. It is also found in the Constitution of the United States of America, where it is provided that habeas corpus shall 'not be suspended, unless when in cases of Rebellion or Invasion the public Safety may require it'. ${ }^{134}$ Even then,

127. Murray v. Carrier [1986] 477 US 478, at 494.

128. Blackstone, above n. 2, at 120.

129. Ex parte Walsh v. Johnson, In re Yates [1925] 37 CLR 36 (HCA), at 79 per Isaacs $J$

130. $R$ v. Carter; Ex parte Kisch [1934] 52 CLR 221 (HCA), at 227 per Evatt J.

131. Per Lord Atkin, Liversidge v. Anderson [1942] AC 206 (HL), at 244

132. Thus, Lord Browne-Wilkinson said in Tan Te Lam v. Tai A Chau Detention Centre [1997] AC 97, at 114, that courts must be astute to ensure that the protection afforded to human liberty should not be eroded save by the clearest of words.

133. Per Hammond J, Zaoui v. Attorney General, para. 126, referring to the House of Lords judgment in Liversidge v. Anderson [1942] AC 206 $(\mathrm{HL})$, where their Lordships held, deferring to the Home Secretary, that 'reasonable cause to believe' that anyone was of hostile origin or association in the Defence (General) Regulations 1939 must be subjectively within the discretion of the executive to determine. See also Green v. Home Secretary [1942] AC $284(\mathrm{HL})$

134. Art. I, Section $9 \mathrm{cl}(2)$ 
Lord Atkin in his lone dissent in Liversidge v. Anderson, ${ }^{135}$ warned about judges being more executive minded than the Executive. Thus, where, as in Zaoui v. Attorney General, the Crown, for all practical purposes, was contending that habeas corpus was suspended during this period in which the plaintiff deemed a security risk was detained pending his removal or deportation, notwithstanding the remedy provided for in Section $1140(2)(c)$, Hammond J held that a court should take a great deal of convincing on such a startling proposition. ${ }^{136}$

\subsection{2 'Enemy Combatants' Equally Entitled to \\ Enjoy Their Privilege to Habeas Corpus}

It is important to preface the controversy that surrounded the 'enemy combatant' case with a brief discussion of the attitude of the courts in the United States which tilts towards an enlarged approach to the concept of custody for the purposes of habeas corpus. Originally, the courts in the United States were of the view that habeas corpus would only lie where a favourable judgment would result in immediate release from all forms of detention. ${ }^{137}$ Since then, however, the concept of custody has greatly expanded to permit a wider use of habeas corpus for the protection of prisoner's rights. For instance, speaking in Fones v. Cunningham ${ }^{138}$ on the scope of habeas corpus reflecting its fundamental purpose, the court held that:

[i]t is now and never has been a static narrow formalistic remedy; its scope has grown to achieve its grand purpose - the protection of individuals against erosion of their right to be free from wrongful restraints upon their liberty. ${ }^{139}$

The question the US Supreme Court had to answer in Boumediene v. Bush ${ }^{140}$ was whether the petitioners had the constitutional privilege of habeas corpus, a privilege not to be withdrawn except in conformance with the Suspension Clause, Article 1, $\$ 9$, clause 2. ${ }^{141}$ The major-

135. [1942] AC $206(\mathrm{HL})$, at 244.

136. Zaoui v. Attorney General, para. 126. Later at para. 157, Hammond J held: "In my view, the terms of the relevant provisions are such that the availability of habeas corpus is always speaking, to the fullest extent, from the inception of the detention process until its completion. I think that is plain on the face of the statute. But even if that were not so, there is a very heavy onus on proponents of the Crown's proposition to make out their case, for the reasons I have already given. Indeed, I would go as far as to say that if habeas corpus is not, continuously speaking, from beginning to end of the detention process, then Parliament really would have to say so unequivocally, and consequentially, be prepared to explain why, in face of its (assumed) international obligations, and its domestic undertaking in the New Zealand Bill of Rights Act 1990, it had chosen to suspend habeas corpus to the extent suggested."

137. McNally v. Hill 293 US 131 (1934)

138. 371 US 236 (1863), at 243.

139. See also American Jurisprudence 2 nd ed., vol. 39, para. 11

140. 553 US 723 (2008); 476 F 3d 981 (2008).

141. In Felker v. Turpin 518 US 1051 (1996), the Supreme Court held that Title 1 of the Anti-Terrorism Act and Effective Death Penalty Act 1996 which works substantial changes to chapter 153 of Title 28 of the United States Code, which authorises federal courts to grant the writ of habeas corpus, does not preclude the court from entertaining an appli- ity of the court held that the petitioners, who were aliens designated as enemy combatants and detained at the US Naval Station at Guantanamo Bay, Cuba, do have the habeas corpus privilege to challenge the legality of their confinement; that Congress had enacted a statute, the Detainee Treatment Act of 2005 (DTA), 119 Stat. 2739 prescribing certain procedures for review of the detainees' status and that those procedures were not an adequate and effective substitute for habeas corpus. Therefore, $\$ 7$ of the Military Commissions Act of 2006 (MCA), 28 USCA §2241(e) (Supp. 2007), operated as an unconstitutional suspension of the writ. Delivering the opinion of the court, Kennedy J said:

Although we do not hold that an adequate substitute must duplicate $\$ 2241$ in all respects, it suffices that the Government has not established that the detainees' access to the statutory review provisions at issue is an adequate substitute for the writ of habeas corpus. MCA $\$ 7$ thus effects an unconstitutional suspension of the writ.

In addition to the foregoing, habeas corpus has been used:

- To challenge the validity of a sentence yet to be served. ${ }^{142}$

- To challenge the validity of a condition of confinement in the form of prison regulation which limited the access of illiterate inmates to the courts by forbidding their fellow prisoners from serving as jailhouse lawyers. It was held that the unlawful regulations made the custody unlawful. ${ }^{143}$

- To challenge the validity of various forms of segregated confinements in a prison on the ground of a violation of due process. ${ }^{144}$

- To bring a prisoner or other detainees such as an institutionalised mental patient, before the court so as to determine the lawfulness of the detention or imprisonment. It is used to examine any extradition process used, amount of bail, and the jurisdiction of the court. ${ }^{145}$

cation for habeas corpus relief, although it does affect the standards governing the granting of such relief. So, too, the availability of such relief in the Supreme Court obviates any claim by petitioner under the Exemption Clause of Art III, §2, of the Constitution, and that the operative provisions of the Act do not violate the Suspension Clause of the Constitution, Art. 1, $\$ 9$.

142. Peyton v. Rowe 391 US 54 (1968)

143. Johnson v. Avery 393 US 483 (1969).

144. McCollum v. Miller 695 F 2d 1044 (7th Cir. 1982); Krist v. Ricketts 504 F 2d 887 (5th Cir. 1974); Bryant v. Harris 465 F 2d 365 (7th Cir. 1972); Dawson v. Smith 719 F 2d 896 (7th Cir. 1983); and Streeter v. Hopper 618 F 2d 1178 (5th Cir. 1980).

145. For instance, in Knowles v. Mirzayance 556 US 111 (2009), Justice Thomas held for the court that a federal court may grant a habeas corpus application arising from a state court adjudication on the merits if the state court's decision 'was contrary to, or involved an unreasonable application of, clearly established Federal law, as determined by the Supreme Court of the United States'. 28 USC $\$ 2254(d)(1)$. In this case, the respondent claimed ineffective assistance of counsel because his attorney recommended withdrawing his insanity defence. The California courts rejected this claim on state post-conviction review. The Supreme Court had to decide whether this decision was contrary to or an unreasonable application of clearly established federal law and held that it 
- Other uses of habeas corpus include immigration or deportation cases and matters concerning military detentions, court proceedings before military commissions, and convictions in military court.

- Finally, habeas corpus is used to determine preliminary matters in criminal cases, such as: (i) an adequate basis for detention; (ii) removal to another federal district court; (iii) the denial of bail or parole; (iv) a claim of double jeopardy; (v) the failure to provide for a speedy trial or hearing; or (vi) the legality of extradition to a foreign country. ${ }^{146}$

Attention need to be drawn to the fact that apart from enjoining the courts to, in appropriate circumstances, disregard the technical language used and liberally construe habeas corpus laws, the American Furisprudence also states that

a person who applies for a writ to secure the release of another must show some interest in the person or some authorisation to make the application. According to some authority, a mere stranger, or volunteer, having no authority derived from the person detained or the legal right to the custody of such a person, has no right to a writ habeas corpus to obtain the discharge of such person from custody. However, there are cases in which the writ has been issued on the application of a stranger or volunteer who bore no legal relation to the person in custody, or who was actuated solely from humanitarian motives. In such cases, the applicable rule is that a person may apply for habeas corpus for another if he sets forth in the application a reason or explanation satisfactory to the court showing why the detained person does not make the application himself. ${ }^{147}$

\section{Conclusion}

The writ of habeas corpus has survived as a portent instrument at the disposal of persons to fight against any encroachment on their personal liberty. The application of the writ in securing personal freedom is pervasive as demonstrated by judicial pronouncements, providing reliefs against any form of unlawful restraint to the liberty of the person. Even persons politically regarded as enemy combatants are not excluded from reliefs of habeas corpus.

The realisation of the fundamental nature of personal liberty to human existence has galvanised the judicial stance against any attempt, whether by executive or legislative acts, to restrict the application of the writ. The stance by the courts that the onus of proof of the legality of the detention rests on the person having the custody of the detainee further strengthens the position of the detainee in seeking relief through the application for the writ of habeas corpus.

The American position that confers locus standi on persons not necessarily connected with the detainee to apply for habeas corpus on behalf of the detainee if they are able to set forth in their application a reason or explanation satisfactory to the court showing why the detainee is unable to personally bring the application, if generally accepted in other common law jurisdictions, would greatly empower the various human rights bodies and other non-governmental organisations to seek, through judicial process, the release of persons in long detentions whose voices could not be heard for political reasons or indigence. Such is prevalent in those nations with nascent democracies as they transit from the regime of absolute rulers or military dictatorships that rarely tolerate the voices of opposition. A recourse to this common law device of habeas corpus would certainly provide the much-needed succour for detainees if the courts of those nations are willing to exhibit the same robustness in upholding the tenets of the writ as witnessed in the decisions of courts from the more advanced democracies.

was not. And that whether reviewed under the standard of review set forth in§2254(d)(1) or de novo, Mirzayance failed to establish that his counsel's performance was ineffective. See also Strickland v. Washington 466 US 668 (1984).

146. Available at www.law.cornell.edu/wex/habeas_corpus (last visited 8 May 2016).

147. American Jurisprudence 2 nd ed., vol. 39, paras. 4 and 117 respectively. 